\title{
The Reflection of Geometric Forms to Abstractions in Turkish Art of Painting
}

\author{
Birsen Çeken ${ }^{1}$, Gökçen Çelik ${ }^{2}$ \\ ${ }^{I}$ (Graphic Design Department, Art and Design Faculty/Gazi University, Turkey) \\ ${ }_{2}^{2}$ (Graphic Design Department, Art and Design Faculty/ Gazi University, Turkey)
}

\begin{abstract}
Geometric expressions and geometric tendencies we see in various places and objects from graffiti to vases whether there is an artistic concern or not entered the art of painting in the West mostly in $20^{\text {th }}$ century together with $19^{\text {th }}$ century and had its modern meaning. As a result of the influences caused by the social events experienced, forms and geometric parts were frequently used in abstractions having a boom and language of expression. As the most important event influencing the West in the field of art did not have a similarity in our country which did not include in The Second World War as our art infrastructure, these developments were reflected in a delayed manner. Some attempts starting with transferring what was in the West without changing at first and the artists found their own styles with the effect of the efforts to reflect the objectives new Turkey had established in this period, and they were individuated. In the current study, the transformation and reflections of geometric forms to abstractions in Turkish art of painting in line with the developments in the West was investigated in a periodical order.
\end{abstract}

Keywords: Modern Turkish Painting Art, Abstraction, Abstract Art, Geometric Forms

\section{INTRODUCTION}

Before questioning geometric seeking in abstraction, let's focus on the question "What is abstract and abstraction?". Abstraction is related to mysterium tremendum called by thinkers of ancient ages and dealt with today's concept of concern (Bonfand, 1994: 11). "Abstraction is the process of reducing the content of a concept or in other words, the strategy of simplifying it" (Şener, 2010: 9). The term of abstraction is thought to have been used by Worringer for the first time. Worringer is also the first to put forward the notion of abstraction as an aesthetic data and the writer of the text Abstraction et Einfühlung [Abstraction and Einfühlung] (Bonfand, 1994: 10). When it comes to the evaluation of abstraction concept within the art, it is likely to mention the concepts of abstract and abstraction together with plainness. When an artist makes abstraction in his work, he will realize this plainness inside him, reflecting his own world.

"In the post-war period when abstract art spread in the West, Turkey started to increase its relations with the outer world. Following the western art closely, Turkish arts made some clues with regard to the tendency towards abstraction in the late 1940s" (Kalkan, 2006: 27, from the thesis of Sabri Berkel). The attempts of abstraction date back to the time before this movement to early impressionist period. Being the basic expression form of modernizing, abstract art "break the human from 'the apparent truth' in the impressionist period step by step and pushed towards new searches" (Antmen, 2008b: 79).

\section{GEOMETRIC TRACKS IN THE ABSTRACTION TENDENCIES IN THE WESTERN ART OF PAINTING}

When we have a look at the period before abstraction attempts in the western sense, we can encounter with abstract expressions in local cultural components of a great many nations. Such local values as Japanese stamps (press work on silk), black masks (African art), Islamic calligraphy appeared as local values but it is likely to see that abstracting expression was also used in the components taking their places in universal values (Tansuğ 1997, Özden 1996). There is an inspiration of the culture where the human being is born in every object he produces, any idea he puts forward. This case is also valid for the works of art produced in the hand and soul of man. The artist will certainly leave some tracks from his culture in the work of art appearing in mind first and produced with soul and manual skills. Turkish artists revived the samples bearing intensive artistic values having the references of their local abstractive forms such as miniature, tile work, tapestry, carpets and so on in abstraction (Tansuğ, 1997: 224). Depending on all these, it is likely to see that abstraction goes back to very early ages but the main thing that I would like to deal with is the abstraction efforts in modern sense and that these efforts lead to abstract art movement.

At the end of $19^{\text {th }}$ century, a great many movements emerged in the art of painting. New tendencies, 
searches and efforts appearing at art never flourished suddenly and without a reason. All of them were born as a result of a painful pregnancy, spreading and developing. Every movement is born of a concern. Then, what were the concerns making the artist break off the effort to reflect nature as it was that was foreseen by Renaissance and guiding him to try new expressions? The most important ones were the invention of the camera and of course industrialization. The invention of camera faded the interest in the works where reality was reflected in an exact way and forced the artist to seek for different ways to express and reflect himself. This seeking led to a great many movements and these movements also led to abstraction (Şener, 2010: 18). This industrial innovation entering our life affected art as well and brought about a must of innovation at art. Artists started to look for new ways of expressions in order to express themselves in their works. As a matter of fact, what forced the artist to do that was not only the invention of the camera. The fact that the opportunities of mass production made a heavy weather of artists brought about a big inner discomfort in the world of art and pushed them to react to it. Such attempts to break the forms and put the inner world of him in the forefront actually emerged as a reaction to all these universal and local changes as well. The first reaction was made by cubists and expressionists artists having a big role in the emergence of abstract art by breaking the real form of an object into parts (Baydın, 2004: 36-37-38).

As a matter of fact, every object is in a geometric plane. We can place an apple into a circle, a pear into a triangle, a glass into a rectangular. One of the techniques taught in drawing methods is to place objects into geometric forms first and then make it apparent (optic) form. Therefore, the perception of nature through geometric forms and turning objects merely geometric forms by taking them out of the forms likely to see through the naked eye is actually turning to the origin, in other words making it plain and abstraction.

According to Özden extracted from Akdeniz (1996):

(...) the perception of the world with a perspective showing the places and locations of the objects from Renaissance onwards has changed and it has been replaced by a new perception not based upon optic vision without a perspective and leading to the real judgements of objects and real form relations. With a start to perceive the objects in geometric structures, a new nature and a world of essences comprising the core of objects were started to obtain. An orientation to the super sensuous universe through science was first found in the paintings of Cezanne in art. Cezanne points out that he would like to depict nature according to cubes and cones. Objects are perceived as plain geometric forms, cylinders, cones and cubes. It means to take the nature out of a visible optic world, a sensual world and make it a nature that could be considered (p 8-9).

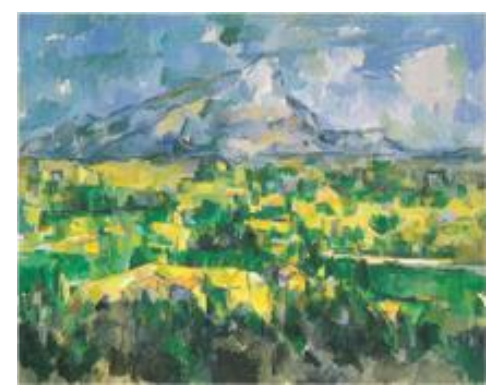

Painting 1: Paul Cézanne, Mont Sainte-Victoire, 1905

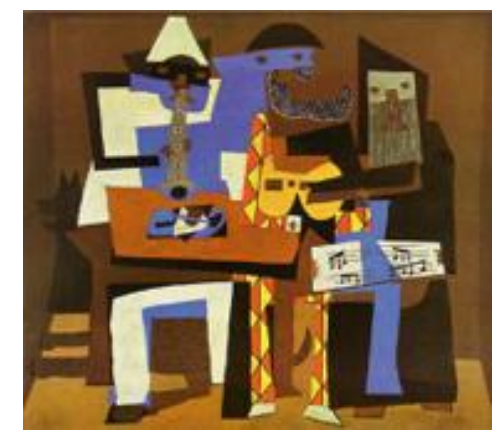

Painting 2 : Pablo Picasso, Three Musicians, 1921, Oil Paint 


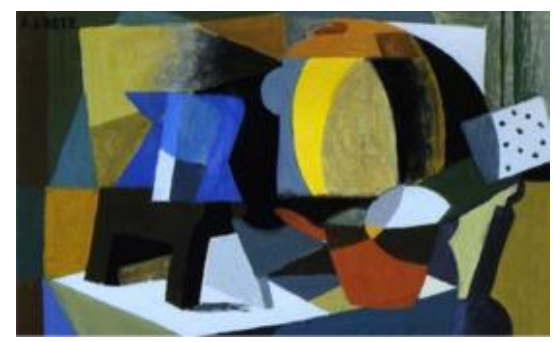

Painting 3 : André Lhote, Abstract Still Life, Water Paint

In all movements emerging after this vision put forward by Cezanne setting a way between expressionism and cubism, we encounter a geometric order (Painting 1). Particularly, such artists as Picasso, Lhote, Braque frequently applied in their works to the method of separating geometric elements, figures and objects into geometric parts in their own period, however, these are not pure abstract works of art (Painting 2-3). Their exposure to the objects in an order is only a tendency of abstraction.

\section{THE EMERGENCE OF ABSOLUTE ART OF ABSTRACTION AND USING GEOMETRIC COMPONENTS}

This journey starting to have an abstract tendency in painting with the wind of isms was improving with the fixation of abstract context to the art completely. This perception declares its limitlessness as an "abstract art" alone in the $20^{\text {th }}$ century in the West. Abstract art, one of the first recalled expression regarding "modern art", revealed itself not only in France which was the art centre of the period, but also in such countries as Germany, Austria, the Netherlands and Russia intensively between the years $1910-1920$ and this new perception comprised of different tendencies and seeking of different forms of such artists as Malevich, Mondrian, Brancusi, Tatlin (Antmen, 2008b: 80) (Painting 4-5). It is not a coincidence to have both the end of the Second World War and abstract art at the same time since it is likely to see the Second World War and the results of it among the primary reasons of abstraction quest. The impacts of changes such as the depression people trying to heal the wounds of the war experienced, industrialization following it, awaking of individualism idea and migration from the rural to urban area showed itself in art, trying to break the artist away from the efforts of conveying what is seen through the naked eye. What is observed in works was not the reality of apparent and viewed the world anymore but the impulse of the artist. When we have a look at the earlier samples of abstraction, we can see this impulse on the wall paintings. These plain forms emerging with an effort to tell what is planned to convey in its easiest way now come to the fore in the form of a means of purpose, conveyance effort by the artist. I would like to convey a good determination in this sense. According to Cauquelin conveying from Worringer:

(...) the artistic urge at the beginning is nothing to do with the imitation of nature. It chases pure abstraction as the only state of stillness in the complexity and darkness of the image of the world and creates geometric abstraction depending on himself in a completely instinctive way. The artistic urge is the only expression of completed and only one suitable for the human being of liberation against all the circumstances and temporality of world image (Cauquelin, 2005: 75).

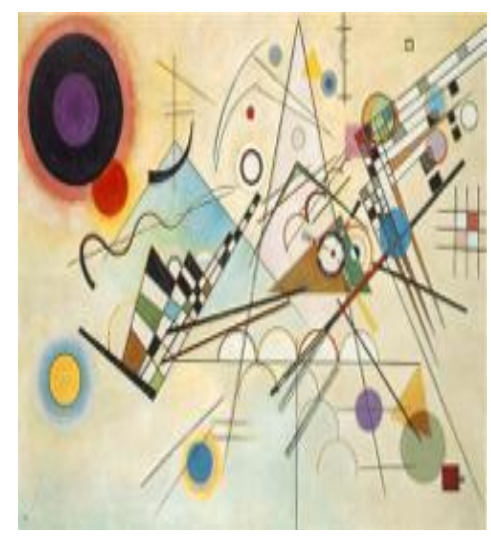

Painting 4: Kandinsky, Composition VIII, 1923 


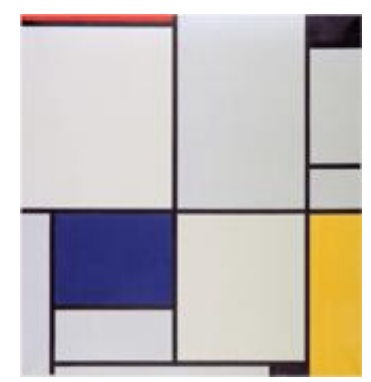

Painting 5: Piet Mondrian, Tableau I, 1921, 103x100 cm, Oil Paint

Geometric forms we started to see in the art of painting with Cezanne went on with the melting of optic forms of objects in cubism. However, geometry in supremacism put forward with the effect of Futurism and Cubism by Malevich as the first geometric abstraction sample in Russia got rid of the context and concern for context. The best example for this could be given as "Black Square" painted on white by Malevich in 1913 (Şener, 2010: 51 -52).

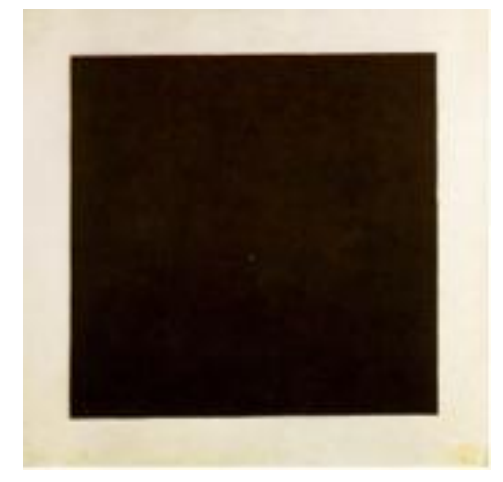

Painting 6: Kazimir Malevich, Black Square, 1913, 106.2x106.5 cm, Oil Paint

IV.

THE ABSTRACTION IN TURKISH ART OF PAINTING

Such movements as Cubism, Neo-Plasticism, Suprematism have not been fully experienced in Turkish Art of Painting. Even though there have been some trials, they have become nothing more than trials. It was actually a lacking for Turkish Art of Painting but it was not a handicap for our painters to catch the time; since if the shortage of these things were a handicap to catch the time, US would not be the cradle of modernism. As is known, all these "isms" in the mid $19^{\text {th }}$ century were not experienced in the USA thoroughly (Ateş, 1988: 22).

While the breaking away from the Renaissance tradition in the West and transition to abstraction went on step by step, accumulating and improving, the transition in our country was so abrupt, as what was experienced in Europe and those experienced in our country were not in line. However, as mentioned above, the reason more active than this was that our infrastructure was not ready for it. With this regard, the idea of Nurullah Berk is as follows: The alienation of Turkish painting to these movements from mid 19th century to 1928-1930s could be considered normal. The country was too far from artistic production and level in Western sense. The community was not ready and deprived of art culture. A sudden adoption of the tendencies having emerged as a production of centuries in the Western sense and imposing on the public would be an inconvenient conveyance (Berk, Özsezgin, 1983: 54).

Another reason for this breakaway and delay is that we have not been dealt with the art of philosophy well enough... there is no movement of art regarded away from philosophical bases. Every movement emerges and improves by taking a thought as a source, criticising what exists, dealing with the effect of social events and making a synthesis. While both the artists and art critics put forward some theories and do reasoning over philosophy of art, it is likely to see that the lack of academic studies carried out over concepts and philosophy of art of both our artists and critics, who were scarce in number, when we have a look at our country particularly in the 1950s. We cannot expect that the concepts which are not discussed can have a strong infrastructure and 
develop well. If we could regard all these things in terms of the new Turkey trying to develop in this period, it would be difficult to say that it is an expectation in vain.

As a matter of fact, as seen in Renaissance Europe, artists were able to survive under the protection of wealthy families having a word on the state or ruling. Then, how much possible was it to support art and artists in that period in the new Turkey trying to develop? This support was able to be felt only a certain period later. I would like to mention about the relation between art and state politics which was quite important for the development of art. This relation has always been important and will also be important. According to Akengin in this respect:

In order that an artist can survive, there is a need for support; otherwise, he cannot improve and maintain art. Any support is not given by the systems and people without any provision or expectation of benefit. However, these supports could sometimes appear in an implicit form and sometimes in an explicit way. In order that an artist personality having no obligation to answer the expectations could be formed, it is essential that that artist is equipped with private chances directly. In this case, the real problem is to create a mechanism that will enable the artist to be equipped with special facilities, in other words, a mechanism that will make him wealthy. Sometimes social perception could create this mechanism and sometimes independent state channels. The artists expecting uncontrolled support cannot understand the main nature of the state as an organized power (Akengin, 2011: 147). Art and artist supported by the state in the new and modern Turkey in time took over the task of working with these modern views adopted by the new Turkey (Akengin, 2014). This task of Turkish artist affected the course of the art in the country. Turkish art of painting has always had a purpose of instilling innovations and making them adopt as a mirror of newly established Turkey.

Turkish painters were not trained in an open air environment where landscape painting was in the forefront rather than figures with the compulsory cultural changing acts coming with the 19th century. Military schools were dominant in this education at first, but civilian people joined in it later on. On the other hand, it is known that some of the Turkish artists sent to the ateliers of western artists for the purpose of training regarded landscape as a problem beyond photography and worked in this tendency (Aypek Aslan, 2016: 87). As it is clearly stated, picturesque expressions in Turkish painting were borrowed as ready-made ones and deprived of local developments (Kurt, 2008: 13). As we haven't adopted, discussed and analysed this concept, there have been some raw parts of the abstract tendencies in the Turkish art of painting.

In the years the 1930s, we see that these years were quite active and innovative years for the artist circles of Turkey. In these years, such different art groups as Independent Group (1928), D Group (1933) and the Group of News (1942). In particular, the artists of Zeki Kocamemi, Ali Çelebi, Sabri Berkel, Nurullah Berk, Refik Epikman and Cemal Tollu in these groups mostly practiced local figures (especially, the method of summarizing nature as geometry that was attempted in the early period of cubism) (Akdeniz 2008, Duben 2007) (Painting 7-8). As in earlier years (the period of military painters generation), artists were sent abroad, particularly to Paris which was the art centre of the period, in order to improve concurrently with the changes and developments of the Western art of world and to exhibit a parallelism in Turkish art circles with Western art. The pioneer of D Group, Nurullah Berk, also went to Paris at that time and had an opportunity to work in the ateliers of artists in Paris. Even though he was not able to benefit from the time he passed in Ernest Laurent atelier in Paris Fine Arts School in his first visit, he managed to create his own form with what was brought with the new art in his works carried out in the ateliers of Andre Lhote and Fernand Leger in his second visit. We can observe the cubist works of Berk and his orientation to local expression step by step in the compositions having a dominance of geometric order by trying to exhibit his works he produced in these years following the foundation of D Group (Berk et al., 1983: 69).

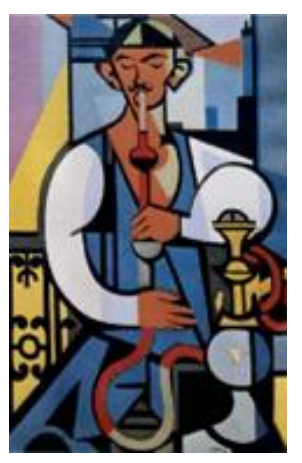

Painting 7: Nurullah Berk, Nargile İçen Adam, (Man Smoking Nargile) 60x93 cm, Oil Paint

İstanbul Museum of Painting and Sculpture 


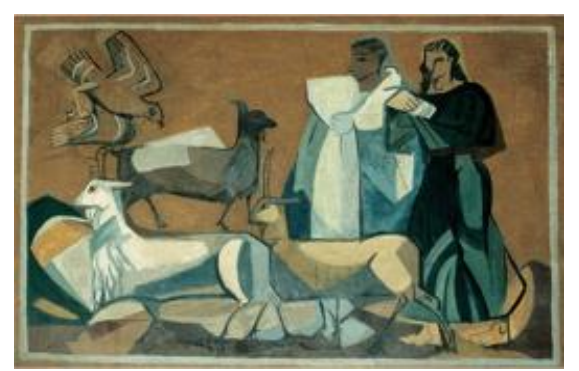

Painting 8: Cemal Tollu, Ankara'da Keçiler, (Goats in Ankara) 90,5x121 cm, on Canvas Oil Paint, İstanbul Museum of Painting and Sculpture, MSFAU Painting Sculpture Collection

The introduction of geometric abstract works to Turkish painting art in real sense was in the years 1945 1950s, following the Second World War. In particular, interest in abstract painting increased in Turkey in the years 1953-1954 and abstract definitions were used in printed media. For that matter, in his writing with a title of "Turkish Painting Today" Bülent Ecevit wrote for the journal of Kültür Dünyası (World of Culture), he used abstract and non-figurative definitions, mentioning about the artists producing works in this sense.

(Özden, 1996: 21). According to Turani:

As the exhibition mentioned in the paper was in early 1954, the related works must have been painted in 1953s. Ecevit showed Cemal Bingöl, Nejat Devrim, Eren Eyüpoğlu and Füreya K1lıç as the pioneers of artists working abstract. Almost one month after the publishing of the paper regarding this exhibition Cemal Bingöl opened a collage exhibition. Fuat Pekin issued a paper with a title of "Abstract Painting" regarding this exhibition. In his paper, he mentioned about Halil Dikmen, Ferruh Başağa, Hasan Kavruk and Salih Urallı who were believed to deal with abstract works (Turani, 1980: 146-147-148) (Painting 9-10).

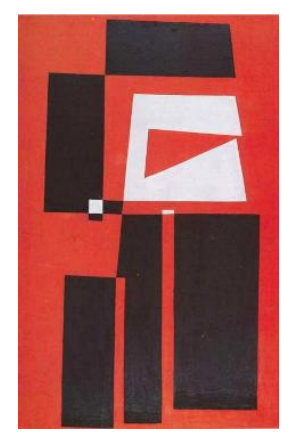

Painting 9: Cemal Bingöl, Abstract Composition, 82x128 cm, Oil Paint on Hardboard $26^{\text {th }}$ State Painting Exhibition $2^{\text {nd }}$ Place Award, Ankara Museum of Painting and Sculpture

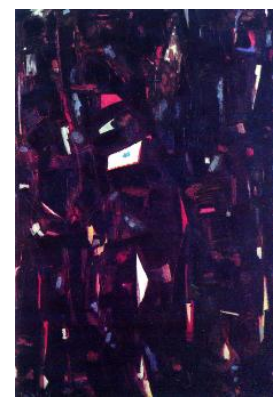

Painting 10: Nejad Devrim, Abstract Composition, 174X185 cm, Oil Paint on Canvas İstanbul Museum of Painting and Sculpture

We mentioned about the reasons for a delay in Turkish painting to catch the time above. If we are to deal a lot more with the issue, it is likely to say that universal and the local social event had an impact on this delay as well as our transition to plastic art past. In an orientation to abstraction in the west, the Second World War had a profound effect but Turkey did not join in the war but felt the influence indirectly. While all the world was fighting against such a big depression, it was impossible for us not to be affected by it. The world was changing and our local changes were also reflected in our art. The results and effects of the Second World War, scientific 
art researches determining the dynamic conditions of the post-war period, transition to multi-party period, the problem of urbanization and population movements caused by social depression all made the artists orient to new seeking, efforts of developing new vision and searches of new criteria (Tansuğ, 1997: 143).

D group was founded in 1933 and geometric abstract works raised in the following years, in particular after 1950. Again, it is known that Elif Naci, one of the painters of D Group, produced some works in the style of geometric abstraction after 1960 (Turani, 1980: 206). The forming in the Turkish painting up to that time was made up of academic Cubism, Impressionism and constructivist works. With their exhibitions opened in 1953, Adnan Çoker and Lütfi Günay giving geometric abstract works became the first painters opening an exhibition made up of abstract works in Turkey (Şener, 2010: 94). Such artists as Nurullah Berk, Adnan Turani, Zeki Kocamemi, Ali Çelebi, Sabri Berkel, Cemal Tollu, Şemsi Arel, Arif Kaptan, Ercüment Kalmık, Erol Akyavaş, Ferruh Başağa, Cemal Bingöl, Elif Naci, Halil Akdeniz, Şükrü Aysan, Tamer Akakmen, İsmail Altınok and Gencay Kasapçı are the ones producing works with geometric arrangements. In particular, the artists like Ferruh Başağa from 1950s onwards, Cemal Bingöl from 1960s onwards and Sabri Berkel, Adnan Çoker, İsmail Altınok and Şükrü Aysan from 1970s onwards got rid of cubist trials with a geometric tendency, used geometric forms alone as a picturesque component in their works (Ateş, 1988: 22-23) (Painting: 11-12).

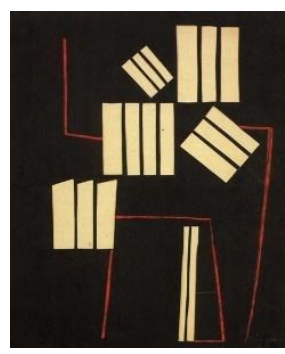

Painting: 11: Adnan Çoker, Hüsn-ü Hat ve Espas (Calligraphy and Space)

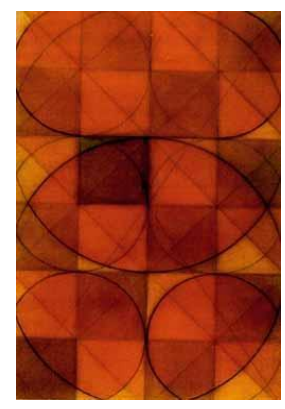

Painting 12: Şükrü Aysan

Adnan Turani classified the artists using geometric elements and produced works in four categories:

a) Geometric Abstractionists

b) Lyric Abstractionists

c) Geometric Non-Figurative

d) Lyric Non-Figurative

(Turani, 1983: 12). The classes we are going to deal with related to our issue are geometric non-figurative and geometric abstractionists. In this sense, let's have a work at non-figurative and geometric abstraction. Depending on the definitions of Alkan Bayraktar:

Geometric Abstraction: It is an action of making new subject forms the ratio of which are almost ordinary within nature by turning into geometric forms or changing their shapes. With this action, the forms of subjects are absolutely broken. As a result of this changing style, there might be an elimination of some details as well as geometricizing the real known and ordinary ratios (Bayraktar, 2011: 9).

Beyond all these, geometric non-figurative perception, as mentioned above, is a conception based on cubism without figure but the one that cannot be without an object. In this conception, contextlessness is important, but color harmony is in the forefront in this conception where strict geometric forms are created. Just like other abstractions, geometric non-figurative paintings refused to use an object as a means of expression. In other words, these works get rid of the subject matters and become something that has no context. It is not a true attitude to think that this contextlessness brings a meaninglessness together with it; as a matter of fact, it should be kept in mind that this kind of paintings has a profound meaning in reality. 
Depending on these definitions, it is likely to say that using geometric forms is a kind of turning back to the essence as both formal (when we have look at the geometric forms observed in such objects as the tapestry, china and so on in the past) and cultural values. Particularly, the local picturesque language with a subject matter of simple daily events and objects by Sabri Berkel and calligraphic based geometric abstraction by Şemsi Arel are good examples for it(Painting 13-14-15-16).

Setting a relation of geometric abstract art with traditional Turkish ornamentation and writing arts was so effective on starting the studies firstly in this direction. The reason for that was the idea that Turkish painting could be created depending on it and it pushed a great many painters in an effort to participate in abstract art and some enthusiastic applications started (Şener, 2010: 86-87).

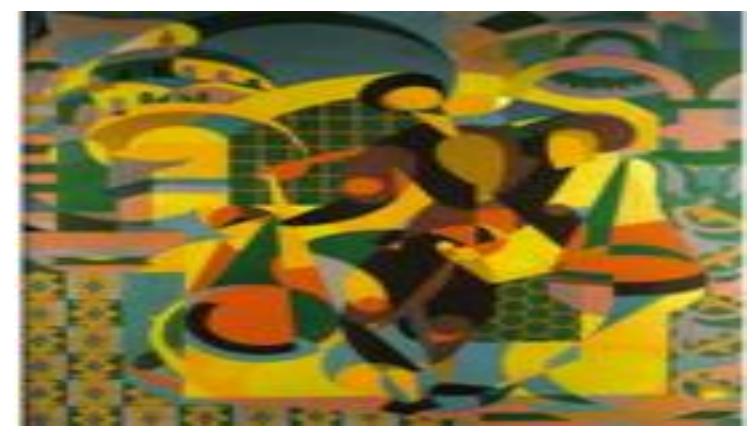

Painting 13: Sabri Berkel, Yoğurtçu II (Yoghurt Seller II), 1954, 162x130, Oil Paint on Canvas

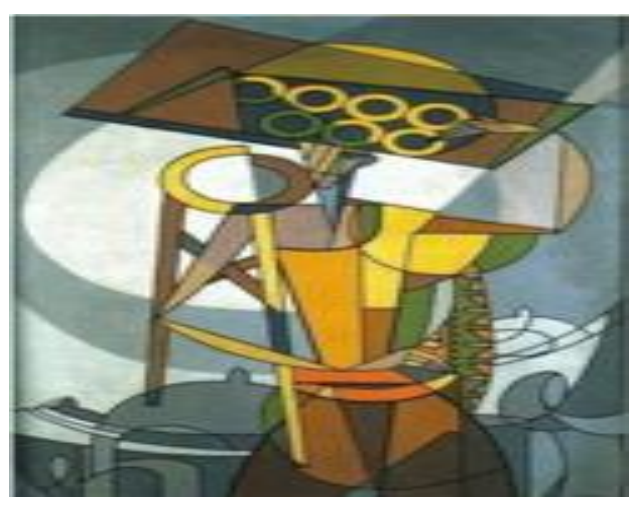

Painting 14: Sabri Berkel, Simitçi, (Bagel Seller) 1952, 162x91cm, Oil Paint on Canvas

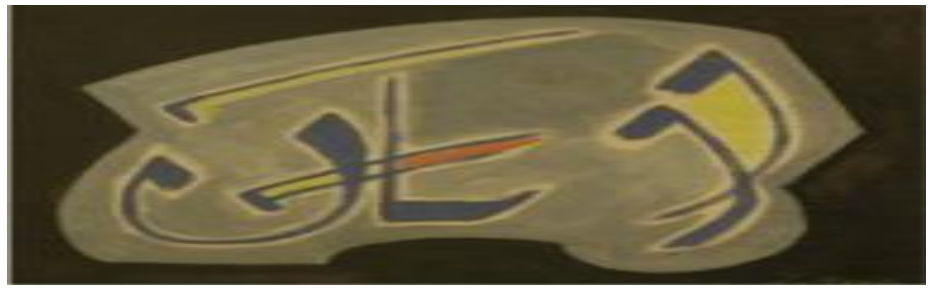

Resim 15: Şemsi Arel, 27x30cm, Oil Paint

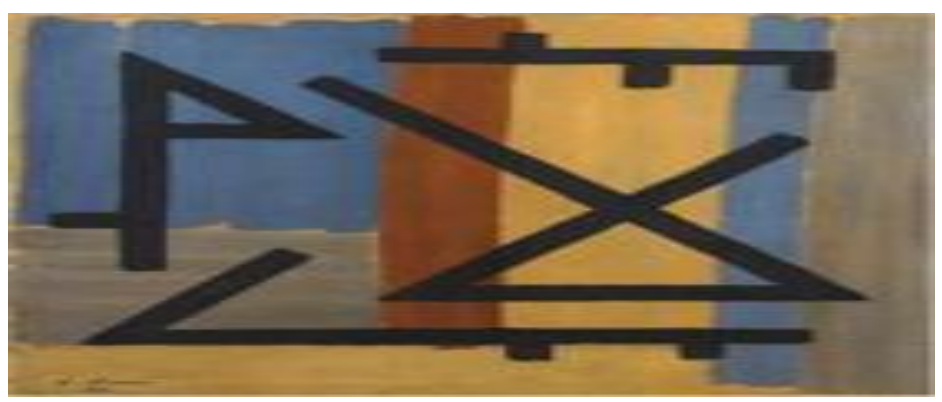

Painting 16: Şemsi Arel, Kufi Kompozisyon, (Cufic Composition) 1956, 70x86 cm, Oil Paint 
As a matter of fact, Sabri Berkel with his subjects bearing simple and traditional components and Şemsi Arel taking Cufic and Islamic calligraphy as a starting point are the best example, as mentioned above, in the place of it in the abstraction of local abstractions. In geometric arrangements, contrary to depicting nature we see so often up to now, it is observed that they broke away from it and traditional conception completely. In 1949, we see that the figure completely vanished in the painting "Aşk" (love) of Ferruh Başağa winning the first place award of Ahmet Çanaklı in the State Painting and Sculpture Exhibition, and he broke away from the model (Painting 17).

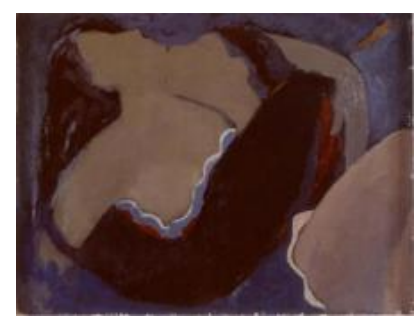

Painting 17: Ferruh Başağa, Aşk (Love)

As a nature of geometric abstraction, the works which were away from the subject completely and in search of a sole order could be seen intensively. As we can see in the later works of Sebri Berker and Ferruh Başağa and sometimes in the works of Fahrünnisa Zeid, Hamit Görele, İsmail Altınok, Halil Akdeniz and Adnan Çoker producing sometimes on geometric non-figurative work, our artists are in search of different things (Painting 18 -19). Particularly in this new expression where figure, model and perspective melted away, the importance of depth, color and style increased. This subject would be regarded as the elements melting away in time. In this way, geometric elements captured the leading position with these new analyses.

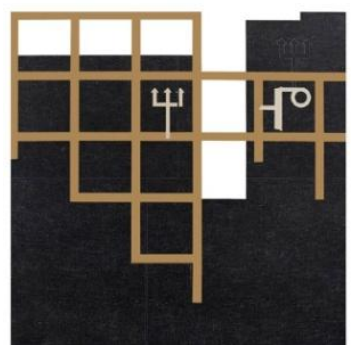

Painting 18: Halil Akdeniz, Kültür Imleri, (Culture Images) 2010, 180x180 cm, Acrylic onCanvas

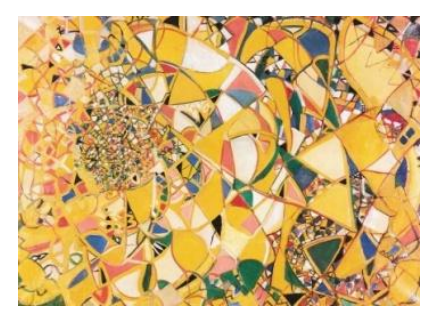

Painting 19: Fahrünnisa Zeid, Abstract Composition

Apart from all these groups, another painter of ours extracted by Adan Turani is Sirrı Özbey who is not mentioned so much but having non-figurative works. According to Turani "painting geometric non-figurative works of art in the 1950s in Balıkesir, Sırrı Özbey was an immigrant and had his training in Sophia Academy for a while" (Özden, 1996: 20) (Painting 20).

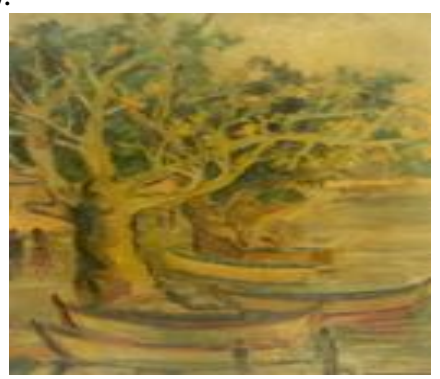

Painting 20: A Painting by Sırrı Özbay in the National Library

As in Sirrı Özbay, there are some interesting examples in the history of Turkish abstract painting. 
Another example for this is Cemil Eren producing significant abstract paintings without an academic training in this field. Cemil Eren left Military in the rank of a lieutenant after completing Military School. He produced works of art focusing on stains rather than colors. He, then, turned to figurative painting and completed his carried in the period when he painted abstract works (Akdeniz, 2008: 203) (Painting 21).

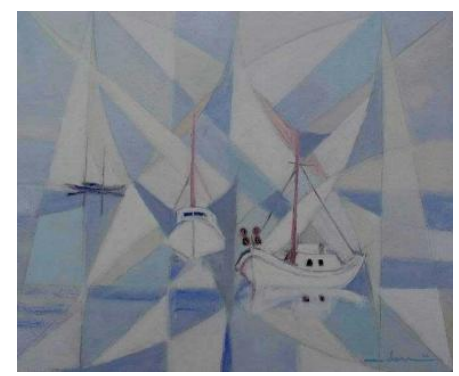

Resim 21: Cemil Eren

\section{CONCLUSION}

It is not possible to think a structure of art without local values. A work of art in conflict with the values of the community, deprived of a free and strong starting point is destined to stay suspended in the air. In this sense, when it comes to the use of geometric forms by Turkish painters in their works, he left the works he inherited from the west initially behind. We see that he took the local values and concepts as the starting point with the works of art becoming free and original, so leaving his mark on Turkish art of painting.

The last thing, perhaps, to remember with regard to such concepts as the economy, politics, policy, industry and war would be "art", but these are the things having an impact on art the most. Nations not being able to meet the basic needs of its people and live a prosperous life do not have time to deal with science and art. That's why this is known to be the factor that our community had a hard time to act in art or delay in it. It is true that the existence of artists producing something is not enough alone to act in art and catch western art. Currently, the deserved attention is not paid to art in our country and those in the field of art are not given the value they deserve as art is not regarded as a "necessary" thing. However, it is necessary that we, as a community, change the perception of "necessity" and be able to succeed to evaluate art out of functionality. If we make our society ready and open for particularly these developments in all sense, we will not experience such kind of delays in the future.

\section{REFERENCES}

[1] Akdeniz, Halil.(2008).“"Türkiye Cumhuriyeti Merkez Bankası. oleksiyonu'ndan Cumhuriyet Dönemi Çağdaş Türk Sanatı”.p.21.p.203. İstanbul

[2] Akengin, Çağatay. (2014). "Sanat İdeoloji Politika İlişkileri”. Ulakbilge Nisan. p.147.

[3] Antmen, Ahu. (2008b). "20. Yüzyıl Batı Sanatında Akımlar". Sel Publishing. p.79-80. İstanbul.

[4] Ateş, İsmail. (1996). "Resimsel Öge Olarak Geometrik Biçimler”. Unpublished Master Thesis Gazi Unıversity. p.22-23. Ankara

[5] Baydın, Ayşe. (1994).“Cumhuriyet Dönemi Türk Resminde Soyut Sanat İfadeciliği”. Unpublished Master ThesisGazi University. p.36-37-38. Ankara

[6] Bayraktar, Alkan. (2011). "Sabri Berkel'in Türk Resim Sanatı İçindeki Yeri ve Önemi”. Unpublished Master ThesisTrakya Unıversity. p.9. p.14. p.21. p.22.Edirne

[7] Berk, Nurullah and Özsezgin, Kaya. (1983). “Cumhuriyet Dönemi Türk Resmi”. TİSA Printing House. p.54. Ankara

[8] Berk, Nurullah and Turani, Adnan. (1980). "Başlangıcından Bugüne Çağdaş Türk Resim Sanatı Tarihi”. Tiglat Art Gallery. p.69. p.146-147-148. İstanbul

[9] Bonfand, Alain. (2015). "Soyut Sanat". Dost Kitabeci Publishing. p.10-11. Ankara

[10] Cauquelin, Anne. (2005). "Çağdaş Sanat". Dost Kitabeci Publishing. p.75. Ankara

[11] Çeken, Birsen., Aypek Arslan, Asuman.(2016). "Landscape Painting in Turkish Art of Painting and

DOI: 10.9790/0837-2110022434 $\quad$ www.iosrjournals.org 33 |Page


Periodical Reflections". IOSR Journal Of Humanities And Social Science Volume 21, Issue 7, Ver. 3 (July, 2016) PP 87-93 e-ISSN: 2279-0837, p-ISSN: 2279-0845. p.87.

[12] Duben, İpek.(2007). “Türk Resmi ve Eleştirisi”. İstanbul Bilgi University Publishing.p.94-95.İstanbul

[13] Özden, Türkan. (1996). "Resimde Geometrik Soyut, Türk Sanatçılarında İlk Yansımaları". Unpublished Master Thesis Gazi University. p.8-9. p.20-21. Ankara

[14] Şener, Şeyda. (2010). p.9. p.18. p.51-52. p.86-87. p.94. "20. Yüzy1l Soyutlama Sürecinde Geometrik Biçimlemenin Türk Resim Sanatına Yansıması”. Unpublished Master Thesis Trakya Unıversity. Edirne

[15] Tansuğ, Sezer. (1991). “Çağdaş TürkSanatı".İstanbul. 